districts but also on more level ground which was covered by glaciers in the glacial period. At the decline of the glaciers they became covered by morainic material and lost to sight. It remains to be seen whether they will stay hidden or whether they will come to light and then be recognised as glacial formations.

MS. received 24 Fune $195^{\circ}$

\title{
POT-HOLES AND GLACIER MILLS \\ SOME COMMENTS ON DR. R. STREIFF-BECKER'S ARTICLE
}

\author{
By S. E. HOLlingworth \\ (University College, London)
}

THE chief obstacle to the solution of this problem is, as Dr. Streiff-Becker indicates, our inability to see the whole process operating at any one place. We must therefore beware of introducing limiting factors of doubtful validity. For instance, would one not be as justified in assuming that a deep pot-hole demands plunge-pool action as in assuming the elimination of the crevasse-toplunge-pool idea by postulation of a thickness of several hundred feet of ice? The elimination of the plunge-pool hypothesis seems to leave us with no adequate agency.

A former glacier bed pot-hole seen in Norway recently was of the order of $20 \mathrm{ft}$. deep plus an unknown thickness of bottom debris. The pot-holes on the Maloja Pass to which Dr. StreiffBecker refers are fine examples of deep cylindrically drilled holes. They are situated on the rocky crest of the pass just where crevassing might be intense.

It is difficult to envisage how sufficient of the essential swirling action could be maintained in a fast flowing subglacial stream to give this type of deep hole if the stream were under a strong hydrostatic head due to high water level in the glacier. Indeed a subglacial stream with a high gradient but in contact with free air and so under no hydrostatic head would provide a better setting.

It is not evident that the subglacial stream hypothesis would account for that apparently accepted concentration of pot-holes at points where crevassing is to be expected. Unfortunately the possible more widespread occurrence of pot-holes beneath drift deposits along valley floors referred to by Dr. Streiff-Becker cannot be readily checked.

A detailed study of the precise location of each deep pot-hole in a glaciated area might reveal an intimate relation to the topography of the rock surface. This might well suggest the possibility of repeated formation of crevasses at favourably located places. Such repitition could give at any such place a surface-water-to-rock-plunge-pool process adequate, in the aggregate, to produce the observed results.

My impression of stream-bed pot-holes in general is that the deep ones are associated with plunge-pool effects in which a free upper water surface is present. Could a similar effect be produced by fast flowing water at the base of waterlogged ice?

We may welcome attention being drawn to this problem, for the whole subject of glacier bed pot-holes and subglacial stream erosion in general merits further study. 


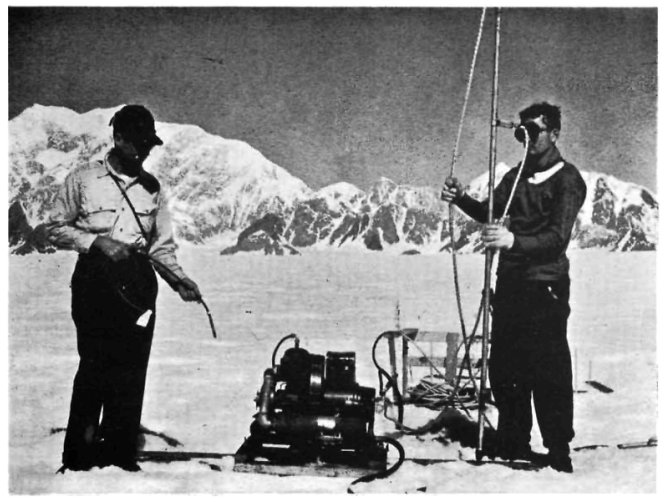

Fig. 2. Thermal boring equipment. Man at left holding thermohm (see text, p. 479)

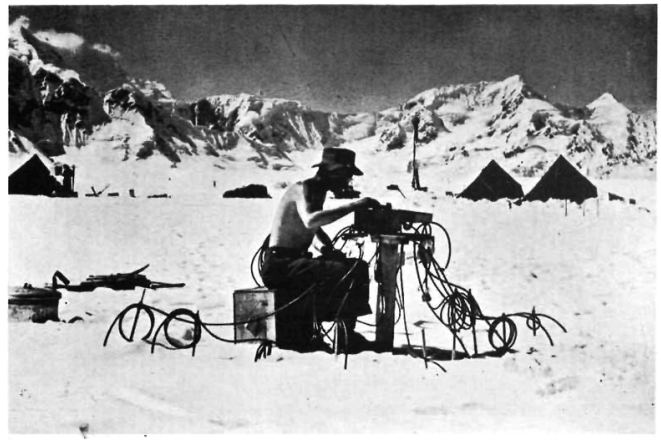

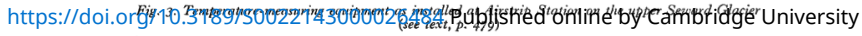
Press 


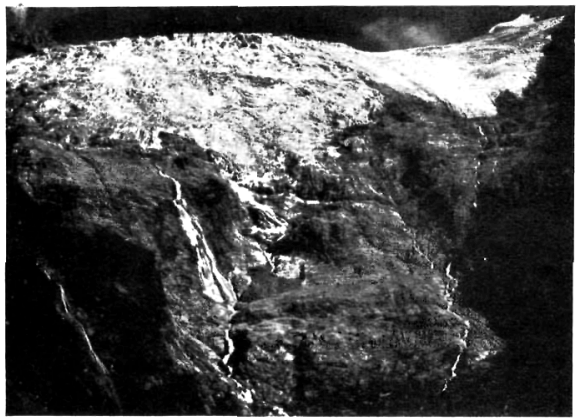

Fig. . . The glacier just before the slide

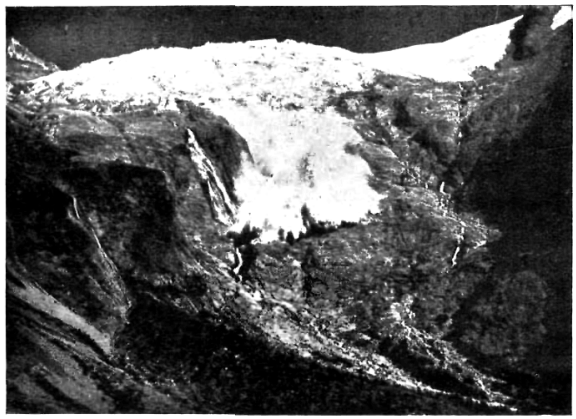

Fig. 3. The commencement of the slide

The Glacier du Tour ice slide (see text, p. soS et seq.)

https://doi.org/10.3189/S0022143000026484 Published online by Cambridge University Press 


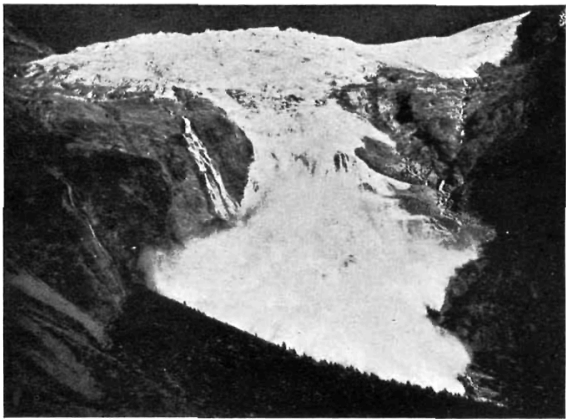

Fig. 4. The ice cloud a few seconds later

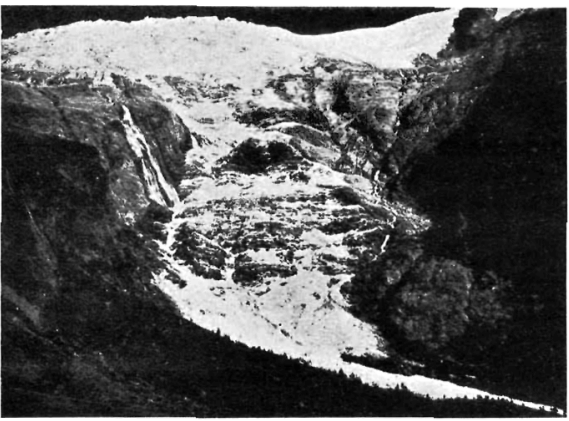

Fig. 5. The glacier at the end of the slide Phowgraphs by R. M. Glaister, reproduced by courtesy of the Editors of " Weather"

https://doi.org/10.3189/S0022143000026484 Published online by Cambridge University Press 

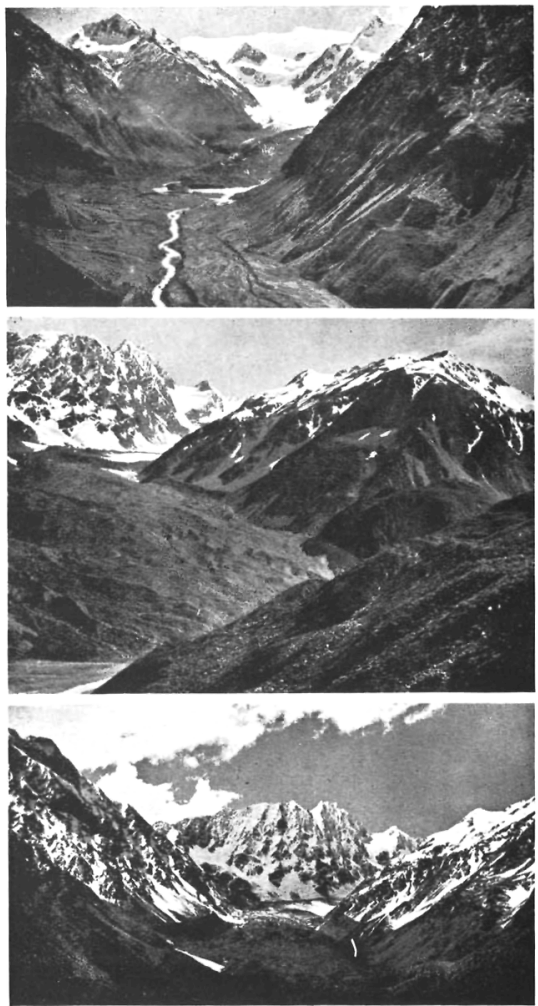

Lyell Glacier from Mein's Knob in 1949. Note recessional moraines and lake, and prominent moraine mound at left. Peaks are, from left to right: Mt. Goethe, Mt. Nicholson and Malcolm Peak (25Io m.) (see text, p. 504 et seq.)

Photograph by $M$. Gage

Ramsay Glacier from Mein's Knob in I9Io, showing stranded lateral moraine on east side, and eastern end of terminal face in contact with fim's Knob. Mt. Whitcombe at left

Photograph by R. Speight

Ramsay Glacier, 1949 , showing further lowering of glacier surface since I9IO

Photograph by M. Gage

https://doi.org/10.3189/S0022143000026484 Published online by Cambridge University Press 